\title{
Haemulidae distribution patterns along the Northeastern Brazilian continental shelf and size at first maturity of the most abundant species
}

\author{
De Melo Catarina Cardoso 1, ", Soares Andrey Paulo Cavalcanti ${ }^{1}$, Pelage Latifa ${ }^{1}$, \\ Eduardo Leandro Nolé ${ }^{1,3}$, Frédou Thierry ${ }^{1}$, Lira Alex Souza ${ }^{1,4}$, Ferreira Beatrice Padovani ${ }^{2}$, \\ Bertrand Arnaud ${ }^{1,2,3}$, Lucena-Frédou Flávia ${ }^{1}$
}

\begin{abstract}
${ }^{1}$ Departamento de Pesca e Aquicultura, Universidade Federal Rural de Pernambuco, Rua D. Manuel de Medeiros, sn, Dois irmãos, CEP 52171-900, Recife, PE, Brazil

2 Universidade Federal de Pernambuco, Departamento de Oceanografia, Recife, PE, Brazil

${ }^{3}$ Institut de Recherche pour le Développement (IRD), MARBEC, Univ Montpellier, CNRS, Ifremer, IRD, Sète, France

4 IRD, Univ Brest, CNRS, Ifremer, LEMAR, F-29280 Plouzané, France

*Corresponding author : Catarina Cardoso de Melo, cmelo.catarina@gmail.com
\end{abstract}

\section{Highlights}

- Haemulidae are broadly distributed through Northeast coast of Brazil due to the complex habitat presents in this region. $-H$. plumierii, $H$. aurolineatum and $H$. squamipinna were considered the most dominant species among the Family. The population structure, and size at first maturity were characterized for the most dominant species of Haemulidae (3 spp.) in Northeastern Brazil. The southern coasts of Pernambuco and Rio Grande do Norte hold high abundance, richness and concentration of juveniles. 
The Haemulidae are one of the most abundant fish families along the Brazilian coast (RANGEL et al., 2007; SOUZA et al., 2007). They inhabit various habitats, but mostly use reef environments because of the resources they provide (SOUTER et al., 2000). They play important ecological roles in the reefs by regulating invertebrate abundance and transferring nutrients across habitats (HOLMLUND \& HAMMER, 1999; APPELDOORN et al., 2009; ARAÚJO et al., 2018). Species of this family are also considered good quality food fishes and are widely consumed across the globe by coastal residents, especially in tropical regions (MUNRO, 1996; LINDEMAN, 2002). In addition, this family is important to the underwater tourism industry because members of this family are often the most abundant on artificial reefs and shipwrecks (UYARRA et al, 2009; HONÓRIO et al., 2010).

According to the latest Brazilian official statistics, 14,000 metric tons of grunts were landed in the Northeast region between 1997 and 2007, which generated a profit equivalent to $\$ 9.3$ million (IBAMA/CEPENE, 1997-2008). The average production per year of haemulids during this period doubled from $711 \mathrm{t}$ in 1997 to $1,550 \mathrm{t}$ in 2007 . Grunts are usually captured by pole and line, traps, and gill nets. They are also a common bycatch of the shrimp trawling fisheries (LINDEMAN, 2002; EDUARDO et al., 2018a; SILVAJÚNIOR et al., 2019). In Northeast Brazil, Haemulon plumierii, H. aurolineatum, and $H$. squamipinna used to be bycatches of the lobster and goatfish fisheries (LESSA et al., 
2009). Currently, haemulids and lutjanids are commonly caught by artisanal fisheries as the target species, owing to the decrease in abundance of lobster and goatfish (LESSA et al., 2009; MARQUES \& FERREIRA, 2013).

Despite their ecological and economic importance, many biological aspects of this family are still unknown or knowledge is restricted in terms of spatial coverage. Available studies do not integrate information about population structure, distribution, abundance, and the habitats occupied by these species. Previous studies in Northeast Brazil have mainly investigated specific aspects of population dynamics, such as the length-weight relationship (EDUARDO et al., 2019), reproduction (SILVA, 2012; SHINOZAKIMENDES et al., 2013a; SHINOZAKI-MENDES et al., 2013b; EDUARDO et al., 2018a), feeding (DE ALMEIDA, 2005; PEREIRA et al., 2015), age, and growth (VASCONCELOS-FILHO et al., 2018; EDUARDO et al., 2018a). According to the regional and global International Union for Conservation of Nature (IUCN) assessments (ICMBio, 2018), haemulids are not under imminent threat and are classified in the Least Concern category, except $H$. plumierii, whose threats are recognized, however, because there is not enough available information for an evaluation the species is categorized as Data Deficient.

The present study investigated the diversity and length at first maturity ( $\left.\mathrm{L}_{50}\right)$ of the main haemulid species in Northeast Brazil. Considering that reefs are highly complex environments that provide areas for reproduction, feeding, and shelter for many different species (LINDEMAN, 2002; ALMARY, 2004), this study also evaluated haemulid distribution, abundance, and special patterns related to habitat use in the area. The findings of this study improve the overall knowledge of haemulids and can be used to assist stock assessments, species extinction risk evaluations, and the detection of priority areas for conservation.

\section{MATERIALS AND METHODS}

\subsection{Study area}

The study area (Fig. 1) comprised of the Northeast Brazilian continental shelf, between the states of Rio Grande do Norte (RN) and Alagoas (AL) $\left(5^{\circ}-9^{\circ} \mathrm{S}\right)$. With a narrow shelf, this eastern part of the Northeast region, located a few degrees north of the 
southern branch of the South Equatorial Current nearshore bifurcation (EKAU \& KNOPPERS, 1999), is demarcated by river mouths and estuaries (KNOPPERS et al., 1999). The relatively low concentration of nutrients and the consequently low primary production mean that fish are not very abundant in the area. However, diversity is generally high across the region (LESSA et al., 2006), and there are several Marine Protected Areas ('Recife de Coral', 'Costa dos Corais', 'Guadalupe', 'Santa Cruz', and 'Barra de Mamanguape') (FERREIRA \& MAIDA, 2007; PRATES et al., 2007).

\subsection{Data collection and sample processing}

Data were collected during the Acoustics Along Brazilian Coast (ABRACOS) surveys that were performed onboard the R/V ANTEA from August 30 to September 20, 2015 (ABRACOS 1; BERTRAND, 2015), and from April 9 to May 9, 2017 (ABRACOS 2; BERTRAND, 2017). The expeditions were approved by the Brazilian authorities, such as the Navy and the Ministry of the Environment (Sisbio). A total of 37 stations, were sampled along the continental shelf $\left(5^{\circ}-9^{\circ} S\right)$ when both expeditions are combined (Fig. 1). At each station, a CTD (model: SeaBird911) was used to examine the oceanographic features (temperature, salinity, and oxygen). Biological samples were collected using a bottom trawl (mesh: $40 \mathrm{~mm}$; bag mesh: $25 \mathrm{~mm}$; mouth dimension: $28 \times 10 \mathrm{~m}$ ). The trawling was carried out at between 15 and $65 \mathrm{~m}$ depth. Each haul lasted approximately 5 minutes and the speed was $3.2 \mathrm{kt}$. Net geometry was calculated using the SCANMAR system, which estimated the height, depth, and width of the net. Bobbins were added to the ground rope on the second cruise in order to reduce the impact on the benthic habitat caused by trawling and to avoid damage to the net.

The habitats were classified by video (see EDUARDO et al., 2018b) using a subaquatic camera. Then the major substrates were identified: eighteen stations (51\%) were classified as sand substrate with rocks, coralline formations and sponges (SWCR), seven as algae (20\%), and six as sand (17\%) (Fig. 2). Four stations (11\%) could not be classified in terms of habitat and were referred to as unknown. The SWCR and algae habitats were found throughout the depth range $(10-60 \mathrm{~m})$. However, the sand habitat was only found in samples near to the shore (10-30 m).

The average width of the continental shelf is $40 \mathrm{~km}$, and the shelf position classification was based on the sampling point distance from the shore. The classifications 
were inner-shelf ( $<20 \mathrm{~km}$ to the shoreline) and outer-shelf ( $>20 \mathrm{~km}$ from the shoreline).

The latitudinal gradient was stratified in accordance with EDUARDO et al. (2018b) who investigated the same area. It was stratified by each $1^{\circ}$, as follows: $A=\left[5^{\circ}-6^{\circ}\right] \mathrm{S}, \mathrm{B}=\left[6^{\circ}-\right.$ $\left.7^{\circ}\right] \mathrm{S}, \mathrm{C}=\left[7^{\circ}-8^{\circ}\right] \mathrm{S}$, and $\mathrm{D}=\left[8^{\circ}-9^{\circ}\right] \mathrm{S}$.

The collected specimens were identified to the lowest taxonomic group while on board the ship. All species belonging to the Haemulidae family were selected and counted in this study. The large samples (>200 specimens) were weighed and 30 individuals were randomly sub-sampled and taken to the laboratory for further analysis. The sub-sampling was conducted only at three stations and, for small samples, all individuals were analyzed. Individuals were preserved in formalin $(4 \%)$ or frozen. At the laboratory, the most abundant species were sorted for population studies. The fish were measured (standard length, SL, in $\mathrm{cm}$ ) and weighed (total weight, TW, in $\mathrm{g}$ ). Then, a ventral-longitudinal incision was performed. The gonads were removed and individuals were sexed and classified as juveniles or adults according to the following macroscopic gonadal development scale for males and females: A: Immature, B: Maturing, C: Mature, and D: Spent (VAZZOLER, 1996).

\subsection{Data Analysis}

\subsubsection{Abundance and diversity}

For each Haemulidae species, the relative abundance index (Catch per Unit of Effort - CPUE) was calculated in terms of biomass $\left(\mathrm{kg} \mathrm{km}^{-2}\right)$ and number $\left(\mathrm{n}^{\circ} \mathrm{km}^{-2}\right)$ where the trawled area was considered to be the unit of effort. The trawled area was estimated by multiplying the distance covered by the net with the estimated net width obtained through the SCANMAR sensors. An average net mouth opening of $13 \mathrm{~m}$ was used for the CPUE calculations. The following formula was used to calculate the CPUE:

$$
\mathrm{CPUE}=\left(\left(\mathrm{n}^{\circ} \text { and } \mathrm{kg}\right) / \mathrm{NW} * \mathrm{SD}\right) * 1000
$$

where: NW $=$ Net Width and SD $=$ Sampled Distance

After checking for normality using the Shapiro-Wilk test and homoscedasticity using the Breusch-Pagan test, the mean CPUE was calculated separately for number $\left(\mathrm{n}^{\circ}\right)$ 
and biomass (kg), and the mean SLs of individuals were tested for possible differences between shelf positions using a t-test $(\alpha=0.05)$.

Species were described by percentage number $(\% \mathrm{~N})$, biomass $(\% \mathrm{~B})$, and frequency of occurrence (\%FO). Minimum, maximum, and mean sizes were also reported for each species. Dominance was determined according to GARCIA et al. (2006), where species were classified according to \%FO and relative abundance (\%CPUE) per latitude point (each $1^{\circ}$ ), shelf position, and habitat type. Species were classified as frequent or rare, and more abundant or less abundant according to their frequency of occurrence and their relative abundance (CPUE), respectively. Based on these classifications, species relative importance indices were determined. They divided the species into four groups: (1) more abundant and frequent, (2) more abundant and rare, (3) less abundant and frequent, and (4) less abundant and rare (according to GARCIA et al., 2006). Species were considered dominant when they were classified into the first, second, and third categories.

\subsubsection{Spatial and population patterns}

The spatial distribution of abundance (based on the CPUE) was plotted for the most frequent species (five spp.). The length at first maturity $\left(\mathrm{L}_{50}\right)$ (length of the fish when $50 \%$ of individuals first achieved gonadal maturity) of the three main species was estimated for pooled sexes and separately. However, as there were no significant statistical differences between males and females, only the pooled sex results were used. The $\mathrm{L}_{50}$ was also used to separate juveniles $\left(<\mathrm{L}_{50}\right)$ and adults $\left(\geq \mathrm{L}_{50}\right)$. L50 was calculated using the percentage of adults by length and the values were adjusted according to King's (2007) logistic equation:

$$
\mathrm{P}_{\mathrm{i}}=1 / 1+\exp -\left(\mathrm{a}+\mathrm{b}^{*} \mathrm{~L}_{50}\right)
$$

where $\mathrm{P}_{\mathrm{i}}$ is the proportion of adults, $\mathrm{a}$ is the intercept, $\mathrm{b}$ is the slope of the curve, and $\mathrm{L}_{50}$ is the mean length at first maturation. The confidence interval was $95 \%$.

The maps were constructed using Qgis, version 3.2.2 software (QGIS, 2018), and the "sizeMat" package (TORREJÓN-MAGALLANES, 2016) in R software (version 3.6.1) was used for the statistical tests and to calculate the $\mathrm{L}_{50}$ values. The length frequency distribution was separately determined for the most abundant species, males, and females, and a t-test was used to identify differences in the mean length between 
170 sexes. As oceanographic conditions at sampling stations were rather similar among surveys, no further analyses addressing environmental parameters and spatial and population patterns were performed.

\section{RESULTS}

\subsection{Oceanographic conditions}

The oceanographic conditions at sampling stations were rather similar among surveys and regions (Supplementary Material1). Bottom temperatures were higher during the second survey performed in summer but overall ranged from $25.5^{\circ} \mathrm{C}$ to $29.6^{\circ} \mathrm{C}$ (mean: $27.5^{\circ} \mathrm{C}$ ), while salinity and dissolved oxygen varied from 36.4 to 37.5 (mean: 36.9) and $4 \mathrm{mg} \mathrm{L}-1$ to $4.4 \mathrm{ml} . \mathrm{L}-1$ (mean: $4.2 \mathrm{ml} . \mathrm{L}-1$ ), respectively.

\subsection{Haemulidae diversity in Northeast Brazil}

A total of 2,976 individuals, belonging to five genera and 10 species, were captured. These were Anisotremus virginicus, Conodon nobilis, Haemulon aurolineatum, H. melanurum, H. parra, H. plumierii, H. squamipinna, H. steindachneri, Haemulopsis corvinaeformis, and Orthopristis ruber. Haemulon aurolineatum and H. squamipinna were dominant in terms of numerical percentage $(\% \mathrm{~N})$, whereas, according to biomass percentage (\%), H. plumierii, $H$. aurolineatum and $H$. squamipinna represented the majority of the total weight captured (83.5\%). The frequency of occurrence (\%FO) results showed that $H$. aurolineatum was the more frequent, followed by $H$. plumierii and $H$. steindachneri (Table 1).

The relative importance index of the 10 species in Northeast Brazil showed that, overall, H. aurolineatum, $H$. plumierii, and $H$. squamipinna were present in most or all areas and were classified as more abundant and frequent (Table 1). The analysis of spatial distribution on the continental shelf showed that most species (nine spp.) occurred in shallow waters on the inner shelf. However, half (five spp.) occurred on the outer shelf. The main species ( $H$. aurolineatum, $H$. plumierii, and $H$. squamipinna) were more abundant and frequent on both shelves. After evaluating the relative importance index by latitude stratum, all species were reported in the $8^{\circ}-9^{\circ} \mathrm{S}$ (D) stratum and four were more abundant and frequent. All species were observed in the SWCR; there were five in the sand habitat (H. aurolineatum, H. plumierii, H. squamipinna, H. steindachneri, and $O$. 
ruber), and three (H. plumierii, A. virginicus, and $H$. aurolineatum) in the algae habitat.

Only H. plumierii had a higher abundance and frequency in all habitats (Table 1).

\subsection{Population aspects and distribution patterns of Haemulidae}

\section{$\underline{\text { 3.3.1 Haemulon plumierii }}$}

Haemulon plumierii individuals ranged from 9.2 to $24.2 \mathrm{~cm} \mathrm{SL}(\overline{\mathrm{X}}=16.6 \mathrm{~cm} ; \mathrm{SD}$ \pm 3.9 ) and from 23.1 to $385.7 \mathrm{~g}$ TW ( $\bar{X}=150.3 \mathrm{~g}$; SD \pm 93.7) (Table 1). A total of 105 individuals were used to estimate the $\mathrm{L}_{50},(13.9 \mathrm{~cm} \mathrm{SL} ; \mathrm{CI}=13-14.7)$ (Fig. 3) and 72.5\% of the collected individuals were classified as adults. The most common length class for females and males was 17-19 cm SL (Fig. 3), and males were significantly larger than females $(t$-test $, \mathrm{t}=-3.56, \mathrm{df}=104.93, p$-value $=0.00056)$.

Haemulon plumierii was widely distributed on the northeast coast and the highest CPUEs ( $\mathrm{n}^{\circ}$ and $\mathrm{kg}$ ) were observed in the southern region of Pernambuco (PE) State ( $8^{\circ}-$ $9^{\circ}$ ) (Fig. 4). There were no significant statistical differences in the mean $\mathrm{n}^{\circ}$ and $\mathrm{kg}$ CPUE values $(t$-test $, \mathrm{t}=0.76, \mathrm{df}=6.77, p$-value $=0.47$ and $\mathrm{t}=0.040, \mathrm{df}=9.11, p$-value $=0.97$, respectively) or the mean lengths of the species found on the inner and outer shelves ( $t$ test $, \mathrm{t}=-2.17, \mathrm{df}=10.99, p$-value $=0.053)$. The juveniles were only found on the inner shelf in the southern region of Paraiba (PB) and in the central region of PE. However, the adults were dominant across the whole area (Fig. 4).

\subsubsection{Haemulon aurolineatum}

Haemulon aurolineatum individuals ranged from 4.5 to $19.5 \mathrm{~cm} \mathrm{SL}(\bar{X}=14.1 \mathrm{~cm} ; \mathrm{SD}$ \pm 2.2 ) and from 1.9 to $120.3 \mathrm{~g} \mathrm{TW}(\overline{\mathrm{X}}=72.6 \mathrm{~g}$; $\mathrm{SD} \pm 26.2)$ (Table 1). A total of 210 individuals were used to estimate the $\mathrm{L}_{50}(11.7 \mathrm{~cm} \mathrm{SL} ; \mathrm{CI}=11.1-12.2)$, and $69.4 \%$ of the specimens were adults (SL > L 50 ) (Fig. 3). The 13-15 cm and 15-17 SL cm length classes were the most common for females and males, respectively (Fig. 3). Males were slightly larger than females $(t$-test $, \mathrm{t}=-2.45, \mathrm{df}=264.24, p$-value $=0.015)$.

Haemulon aurolineatum occurred throughout the study area (RN to PE), with higher CPUE values ( ${ }^{\circ}$ and $\mathrm{kg}$ ) reported in RN and in the southern part of PE (Fig. 5). There were no significant differences in the mean $\mathrm{n}^{\circ}$ and $\mathrm{kg}$ CPUEs between the inner and outer shelves $(t$-test $, \mathrm{t}=-0.17, \mathrm{df}=9.34, p$-value $=0.87$ and $\mathrm{t}=0.067, \mathrm{df}=10.70, p$ - 
value $=0.95$, respectively). Individuals were larger on the outer shelf than on the inner shelf $(t$-test $, \mathrm{t}=-3.17, \mathrm{df}=13.88, p$-value $=0.007)$. There was a higher proportion of adults than juveniles, except on the inner shelf south of RN and in PE where juveniles were most abundant (Fig. 5).

\subsubsection{Haemulon squamipinna}

Haemulon squamipinna individuals ranged from 9.2 to $16.3 \mathrm{~cm}$ SL $(\overline{\mathrm{X}}=12.9 \mathrm{~cm}$; $\mathrm{SD} \pm 1.7)$ and from 18.3 to $110.9 \mathrm{~g} \mathrm{TW}(\overline{\mathrm{X}}=60.5 \mathrm{~g}$; $\mathrm{SD} \pm 21.5)$. A total of 58 individuals were used to estimate the $\mathrm{L}_{50}(10.1 \mathrm{~cm} \mathrm{SL} ; \mathrm{CI}=8.6-11)$, and $92 \%$ of the individuals were adults (SL > L50) (Fig. 3). The 13-15 cm length class was the most common for both females and males (Fig. 3). The mean length of females and males was similar $(t$-test, $\mathrm{t}=$ 0.60$, df $=105.40, p$-value $=0.55)$.

Haemulon squamipinna was found in PB and PE, with the highest CPUE $\left(\mathrm{n}^{\circ}\right.$ and $\mathrm{kg}$ ) values reported on the south coast of PE (Fig. 6). The differences between the CPUE $\left(\mathrm{n}^{\circ}\right.$ and $\mathrm{kg}$ ) values for the inner and outer shelves $(t$-test $, \mathrm{t}=-1.08, \mathrm{df}=3.00, p$-value $=$ 0.36 and $\mathrm{t}=-1.13, \mathrm{df}=3.00, p$-value $=0.34$, respectively $)$ and mean length $(t$-test, $\mathrm{p}=\mathrm{t}$ $=-1.21, \mathrm{df}=4.26, p$-value $=0.28)$ were not significantly different. Overall, there was a higher proportion of adults than juveniles, particularly on the inner shelf of the coast along PE (Fig. 6).

\subsubsection{Haemulon steindachneri}

Haemulon steindachneri individuals ranged from 10.7 to $18.0 \mathrm{~cm} \mathrm{SL}(\bar{X}=14.2$ $\mathrm{cm} ; \mathrm{SD} \pm 1.8)$ and from 33.4 to $135.9 \mathrm{~g} \mathrm{TW}(\overline{\mathrm{X}}=78.1 \mathrm{~g} ; \mathrm{SD} \pm 24.5)$. This species was observed on the inner shelf from RN to PE, and southern RN and southern PE had the highest CPUE ( ${ }^{\circ}$ and $\mathrm{kg}$ ) values (Fig. 7).

\subsubsection{Orthopristis ruber}

Orthopristis ruber individuals ranged from 11.1 to $17.8 \mathrm{~cm}$ SL ( $\bar{X}=14.7 \mathrm{~cm}$; SD $\pm 1.3)$ and from 37.4 to $133.2 \mathrm{~g}$ TW $(\bar{X}=83.2 \mathrm{~g} ; \mathrm{SD} \pm 21.4)$. This species was observed on the inner shelf from RN to PE, and southern PB had the highest CPUE ( ${ }^{\circ}$ and $\mathrm{kg}$ ) values (Fig. 8). 
270

\section{DISCUSSION}

This study provides new and integrative information about the diversity, distribution, and population biology of the main haemulids along the northeast coast of Brazil. It contributes to our knowledge on spatial patterns of abundance and habitat use by these species across an Ecologically or Biologically Significant Marine Area (CBD, 2014).

In this study, 10 species of Haemulidae were collected. They comprised of five genera that were dominated by the genus Haemulon. LESSA and NÓBREGA (2000) reported 12 species in the same area, of which nine were present in our study (except $A$. surinamensis, $H$. chrysargyreum, and $H$. macrostomum). However, the $H$. squamipinna collected in this study was not recorded by LESSA and NÓBREGA (2000). A total of 13 Haemulidae species are currently reported to inhabit the Northeast Brazil region when both studies are taken into account. The Northeast region has a greater species richness than other regions due to the high diversity of complex habitats, which means that there are several genera of this family in the region. Furthermore, the Northeast Brazilian coast has a greater species richness than the central coast (four species, COSTA et al., 2007), and all of the central coast species have been observed in the Northeast region ( $A$. surinamensis, A. virginicus, $H$. aurolineatum, and $H$. plumierii). Similar results have been recorded for the southeast Brazilian coast, with 11 species (MENEZES, 2011), of which, seven have been observed in the northeast (A. virginicus, $C$. nobilis, $H$. aurolineatum, $H$. parra, H. plumierii, H. steindachneri, and O. ruber).

The area is also species rich compared to other Atlantic coral regions. The coast of Costa Rica contains seven species (FOURRIÉRE et al., 2017) and the Méxican Atlantic coast contains nine species (GALVÁN-VILLA et al., 2016). Furthermore, in the Indian Ocean region around Western Australia, 10 species and two genera (Diagramma and Plectorhinchus) have been reported (HARRY, 2001). In the Pacific region, the Japanese coast contained a similar number of species (12 spp.) to the northeast coasts of Brazil, although there were only four genera (Diagramma, Parapristipoma, Plectorhinchus, and Pomadasys (currently, Haemulopsis) (MOTOMURA \& HARAZAKI, 2017). Other studies have also reported the high diversity of haemulids in areas with coral reefs (WHITE, 1994; REAKA-KUDLA, 1997; JAIXON-HARM et al., 2012; HONDA et al., 2013), and that they were dominated by the genus Haemulon (BROTTO ET AL., 2007; 
MADRID ET AL., 1997).

Northeast Brazil was dominated by $H$. aurolineatum, $H$. plumierii, $H$. squamipinna, which confirmed other studies on the region (ROCHA et al., 1998; IVO et al., 2010; OLAVO et al., 2011). Species richness was higher on the inner shelf, especially between $8^{\circ} \mathrm{S}$ and $9^{\circ} \mathrm{S}$ where coral habitats predominate. Pernambuco (PE) and Rio Grande do Norte (RN) are considered to be "hotspots" for haemulids due to the high abundances of $H$. aurolineatum (PE and $\mathrm{RN}), H$. plumierii (PE), H. squamipinna (PE), and $H$. steindachneri (PE and RN). Pernambuco has been previously classified as a biodiversity "hotspot" for demersal fishes (EDUARDO et al., 2018b; SOARES, 2019). These areas have several Marine Protected Areas - APA Costa dos Corais and APA Recifes de Coral (FERREIRA \& MAIDA, 2006), patchy reefs, and various artificial reefs (mainly in PE) that provide habitats for fishes and other local fauna (DOS SANTOS et al., 2010). Furthermore, complex sandstone reef formations ("Parrachos") favor the settlement of corals and thus influence the diversity and abundance of fish assemblages (CAMPOS et al., 2010, LOPES et al., 2014), especially in RN where there are a great number of these formations.

In this study, $\mathrm{L}_{50}$ values were determined for $H$. plumierii and $H$. aurolineatum. This study also recorded the first $\mathrm{L}_{50}$ values for $H$. squamipinna in the world. The $\mathrm{L}_{50} H$. plumierii length (15.1 cm FL) was slightly lower than those observed by SHINOZAKIMENDES et al. (2013 $)$. The $\mathrm{L}_{50}$ registered for $H$. aurolineatum $(15.3 \mathrm{~cm}$ TL) was similar to the value reported by LESSA et al. (2004). The differences may be due to environmental conditions and anthropogenic factors, such as fishing, which may lead to the earlier maturation of a stock (OLSEN et al., 2004; LOURENÇO et al., 2015; FROESE et al. 2016), or to methodological differences, for example, the use of different equipment or maturity scales.

The L50 was also used in this study to evaluate the spatial distribution of juvenile and adult haemulids. Although the adults dominated most species and areas, the inner shelf of the PE coast, RN (H. aurolineatum), and southern PB (H. plumierii and $H$. aurolineatum) had a high proportion of older juveniles. According to LINDEMAN (2000), the reef environment is an area in which juveniles near maturation and adults of most haemulid species live and spawn. Haemulids inhabit mangrove areas and seagrass beds during the post-larval and early juvenile phases, and then migrate to the reefs once they reach maturity (MUNRO, 1983; LINDERMAN et al., 2000; DE LA MORINIERE et al., 2002; 2003). 
Some species of the family Haemulidae, such as Conodon nobilis (LIRA et al., 2019), Haemulopsis corvinaeformis (EDUARDO et al., 2018), and Orthopristis ruber (COSTA et al., 2018), are frequently captured as shrimp trawling bycatch. They are caught near the shore and are mostly individuals that are below the size of first maturity (PASSARONE et al., 2019). Species of the genus Haemulon are not widely affected by trawling because they inhabit coral reef areas that cannot be normally reached by the trawling gear. However, species of this genus are often captured in traps (MARQUES \& FERREIRA, 2010). Haemulon plumierii is particularly prone to capture across Rio Grande do Norte and Ceará in Northeast Brazil (LESSA et al., 2004; IVO et al., 2010), and $H$. aurolineatum and $H$. squamipinna are often caught along the coast of Pernambuco (LESSA et al., 2004; MARQUES \& FERREIRA, 2010). Haemulids used to be bycatch of the lobster fishery. However, a sequential depletion of target stocks occurred in the trap fishing areas of Northern Brazil, starting with the most valuable resource, the spiny lobster (Panulirus spp.). Other stocks were then successively targeted, such as goatfishes (Pseudopeneus maculatus), parrotfishes (Scarus spp.), snappers (Lutjanus spp.), and finally grunts (Haemulon spp.) (OLIVEIRA et al., 2015). RIBEIRO (2006) reported that the decrease in the abundance of the trap fishing target species meant that the fishing of other reef species had greatly increased. Haemulidae catches doubled over 10 years according to the Brazilian official statistics (IBAMA/CEPENE, 1997-2008). However, currently, there are no data (statistics and status of the stock) available. This has hampered actions in terms of fishery management and conservation, which could be a concern because this group may experience the same outcome as the previous ones.

Increasing knowledge about the biology of key reef species and their respective relationships with their habitats is essential for identifying priority areas for conservation and, thus, the optimal implementation of marine spatial planning. Additionally, this new information may be crucial to protecting threatened species, especially those living in reef environments that are under several increasing pressures (ARTHINGTON et al., 2016; BAX et al., 2016).

\section{CONCLUSIONS}

For management measures and conservation of haemulids, special attention should be focused on the inner shelf of the southern coast of Pernambuco and Rio Grande do Norte, as these areas are species rich, have high species abundances, and high juvenile biomass. If management plans are to have a broader conservation impact, the 
management actions should address all parts of the shelves between $8^{\circ}-9^{\circ}$ and $5^{\circ}-6^{\circ} \mathrm{S}$. Despite implementation of conservation measures and increased efforts to conserve these ecosystems and species, they are still insufficient to mitigate or reverse the increasing anthropogenic impacts in this important area. The findings of this study suggest that notake areas in already existing Marine Protected Areas should be created or expanded in order to enhance biodiversity and protect stocks within their boundaries.

\section{ACKNOWLEDGMENTS}

We acknowledge the French oceanographic fleet for funding the at-sea survey ABRACOS 1 and 2 and the officers and crew of the R/V Antea for their contribution to the success of the operations. The present study could not have been done without the work of all participants from the BIOIMPACT Laboratory. We thank the CAPES which provided student scholarship to Catarina Cardoso de Melo, Leandro Nolé Eduardo, Alex Souza Lira, Latifa Pelage, and Andrey Paulo Cavalcanti Soares. We also thank CNPq (Brazilian National Council for Scientific and Technological Development), which provided research grant for Beatrice Padovani Ferreira and Flávia Lucena Frédou. This work is a contribution to the LMI TAPIOCA, program CAPES/COFECUB (88881.142689/2017-01), and PADDLE project, which has received funding from the European Union's Horizon 2020 research and innovation programme under grant agreement No 73427. Additionally, this work includes the ILTER site 18 PELD-TAMS/ CNPq. 


\section{REFERENCES}

1. ALMARY, G. R. 2004. Does increased habitat complexity reduce predation and competition in coral reef fish assemblages? Oikos, 106, 275 - 284. https://doi.org/10.1111/j.0030-1299.2004.13193.x

2. APPELDOORN, R.S., AGUILAR-PERERA, A., BOUWMEESTER, B.L.K., DENNIS, G.D., HILL, R.L., MERTEN, W., RECKSIEK, C.W. and WILLIAMS, S.J., 2009. Movement of fishes (Grunts: Haemulidae) across the coral reef seascape: A review of scales, patterns and processes. Caribbean J. Sci., 45 (23), 304-317. https://doi.org/10.18475/cjos.v45i2.a16

3. ARAÚJO, M. E., FEITOSA, C.V., MATTOS, S. M. G. 2018. Ecologia de peixes recifais em Pernambuco, Recife: Ed. UFPE.

4. ARTHINGTON, A.H., DULVY, N.K., GLADSTONE, W. AND WINFIELD, I.J. 2016. Fish conservation in freshwater and marine realms: status, threats and management. Aquat. Conserv., 26 (5), 838-857. https://doi.org/10.1002/aqc.3080

5. BAX, N.J., CLEARY, J., DONNELLY, B., DUNN, D.C., DUNSTAN, P.K., FULLER, M. and HALPIN, P.N. 2016. Results of efforts by the Convention on Biological Diversity to describe ecologically or biologically significant marine areas. Conserv. Biol, 30 (3), 571-581. https://doi.org/10.1111/cobi.12649

6. BERTRAND A. (2015) ABRACOS cruise, RV Antea, https://doi.org/10.17600/15005600

7. BERTRAND A. (2017) ABRACOS 2 cruise, RV Antea, https://doi.org/10.17600/17004100

8. BROTTO, D. S.; KROHLING, W; ZALMON, I. R. 2007. Comparative evaluation of fish assemblages census on an artificial reef. Rev. Bras. Zool., 24 (4), 1157-1162. http://dx.doi.org/10.1590/S0101-81752007000400037

9. CBD. 2014. Pathways of Introduction of Invasive Species, their Prioritization and Management. UNEP/CBD/SBSTTA/18/9/Add.1. Secretariat of the Convention on Biological Diversity, Montréal.

10. CAMPOS, C. E. C., OLIVEIRA, J. C. S., \& ARAÚJO, A. S. 2010. Composição e estrutura de comunidades de peixes nos Parrachos de Muriú, Estado do Rio Grande do Norte, Brasil. Arqu. Ciên. Mar, 43 (1), 63-75. https://doi.org/10.32360/acmar.v43i1.6013

11. COSTA, P. A. S., OLAVO, G., \& MARTINS, A. S. 2007. Biodiversidade da fauna marinha profunda na costa central brasileira (Vol. 24). Museu Nacional.

12. DE ALMEIDA, Z.D.S.; NUNES, J.L.S.; ALVES, M.D.G.F.S. 2005. Dieta alimentar de Genyatremus luteus (BLOCH, 1970) (Teleostei, Perciformes: Haemulidae) na Baía de São José, Maranhão, Brasil. Atlântica (Rio Grande), 27 
(1), 39-47.

13. DE LA MORINIÈRE, E. C., POLLUX, B. J. A., NAGELKERKEN, I., VAN DER VELDE, G. 2003. Diet shifts of Caribbean grunts (Haemulidae) and snappers (Lutjanidae) and the relation with nursery-to-coral reef migrations. Estuar. Coast. Shelf S., 57 (5-6), 1079-1089. https://doi.org/10.1016/S0272-7714(03)000118

14. DE LA MORINIÈRE, E. C., POLLUX, B. J. A., NAGELKERKEN, I., VAN DER VELDE, G. 2002. Post-settlement life cycle migration patterns and habitat preference of coral reef fish that use seagrass and mangrove habitats as nurseries. Estuar. Coast. Shelf S., 55, (2) 309-321. https://doi.org/10.1006/ecss.2001.0907

15. DOS SANTOS, D. H., DA SILVA CUNHA, M. D. G., AMANCIO, F. C., \& PASSAVANTE, J. Z. D. O. 2010. Recifes artificiais, mergulho e pesca artesanal: alguns aspectos do conflito na costa de Pernambuco-Brasil. J. Coast. Zone Manag., 10(1), 7-22.

16. EDUARDO, L. N.; LIRA, A. S.; FRÉDOU, T.; \& FRÉDOU, F. L. 2018. Population structure and reproductive biology of Haemulopsis corvinaeformis (Perciformes, Haemulidae) in the south coast of Pernambuco, northeastern Brazil. Iheringia. Sér. Zool.,108. http://dx.doi.org/10.1590/1678-4766e2018007

17. EDUARDO, L. N.; FRÉDOU, T.; LIRA, A. S.; FERREIRA, B. P.; BERTRAND, A.; MÉNARD, F.; \& FRÉDOU, F. L. 2018. Identifying key habitat and spatial patterns of fish biodiversity in the tropical Brazilian continental shelf. Cont. Shelf Res.,166,108-118. http://dx.doi.org/10.1016/j.csr.2018.07.002

18. EDUARDO, L. N., FRÉdOU, T. LIRA, A. SANTOS, L., FERREIRA, B. BERTRAND, A., MÉNARD, F. LUCENA-FRÉDOU. 2019. Length-weight relationship of thirteen demersal fishes from the tropical Brazilian continental shelf. J. Appl. Ichthyol., Wiley, 35 (2),590-593. https://doi.org/10.1111/jai.13831

19. EKAU, W., KNOPPERS, B., 1999. An introduction to the pelagic system of the north-east and east. Brazilian shelf. Arch. Fish. Mar. Res. 47, 113-132. http://dx.doi.org/0944-1921/99/47/2/3-5/12.00\$/0

20. FERREIRA, B.P. \& MAIDA, M. 2006. Monitoramento dos recifes de coral do Brasil. MMA, Secretaria de Biodiversidade e Florestas.

21. FOURRIÉRE, M., ALVARADO, J. J., BOCOS, A. A., CORTÉS, J. 2017. Updated checklist and analysis of completeness of the marine fish fauna of Isla del Coco, Pacific of Costa Rica. Mar. Biodivers., 47 (3), 813-821. http://dx.doi.org/10.1007/s12526-016-0501-6

22. FROESE, R., WINKER, H., GASCUEL, D., SUMAILA, U.R., PAULY, D. 2016. 
Minimizing the impact of fishing. Fish Fish., 17 (3), 785-802. https://doi.org/10.1111/faf.12146

23. GALVÁN-VILLA，C. M., RÍOS-JARA， E., BASTIDA-IZAGUIRRE, D., HASTINGS, P. A., BALART, E. F. 2016. Annotated checklist of marine fishes from the Sanctuary of Bahía Chamela, Mexico with occurrence and biogeographic data. ZooKeys, 554,139. https://doi.org/10.3897/zookeys.554.6106

24. GARCIA, S. M., \& ROSENBERG, A. A. 2010. Food security and marine capture fisheries: characteristics, trends, drivers and future perspectives. Philos. T. R. Soc. B. https://doi.org/10.1098/rstb.2010.0171

25. HARRY, J. 2001. Biodiversity of shallow reef fish assemblages in Western Australia using a rapid censusing technique. Rec. West. Aust. Mus., 20, 247-270.

26. HOLMLUND, C. M., \& HAMMER, M. 1999. Ecosystem services generated by fish populations. Ecol. Econom., 29(2), 253-268.

27. HONDA, K., NAKAMURA, Y., NAKAOKA, M., UY, W. H., FORTES, M. D. 2013. Habitat use by fishes in coral reefs, seagrass beds and mangrove habitats in the Philippines. PLoS One, 8 (8), e65735. https://doi.org/10.1371/journal.pone.0065735

28. HONÓRIO, P. P. F.; RAMOS, R. T. C.; FEITOZA, B. M. 2010. Composition and structure of reef fish communities in Paraíba State, north-eastern Brazil. J. fish biol.,77 (4), 907-926. https://doi.org/10.1111/j.1095-8649.2010.02728.x

29. IBAMA/CEPENE. Estatística da Pesca 1996 Brasil. Grandes Regiões e unidades da federação. p.134, 1997.

30. IBAMA/CEPENE. Estatística da Pesca 1997 Brasil. Grandes Regiões e unidades da federação. p. 99, 1998.

31. IBAMA/CEPENE. Estatística da Pesca 1998 Brasil. Grandes Regiões e unidades da federação. p. 110p, 1999.

32. IBAMA/CEPENE. Estatística da Pesca 1999 Brasil. Grandes Regiões e unidades da federação. p.121, 2000.

33. IBAMA/CEPENE. Estatística da Pesca 2000 Brasil. Grandes Regiões e unidades da federação. p.46, 2002.

34. IBAMA/CEPENE. Estatística da Pesca 2001 Brasil. Grandes Regiões e unidades da federação. p.124, 2003.

35. IBAMA/CEPENE. Estatística da Pesca 2002 Brasil. Grandes Regiões e unidades da federação. p.129, 2004. 
36. IBAMA/CEPENE. Estatística da Pesca 2004 Brasil. Grandes Regiões e unidades da federação. p.136, 2005.

37. IBAMA/CEPENE. Estatística da Pesca 2005 Brasil. Grandes Regiões e unidades da federação. p.147, 2007.

38. IBAMA/CEPENE. Estatística da Pesca 2007 Brasil. Grandes Regiões e unidades da federação. p.151, 2007.

39. IBAMA/CEPENE. Estatística da Pesca 2006 Brasil. Grandes Regiões e unidades da federação. p. 181, 2008.

40. IVO, C.T.C., VASCONCELOS, A.J., OSÓRIO, F.M. 2010. Pesca de peixes com covos no estado do Rio Grande do Norte. Bol. Téc. Cient. CEPENE, Tamandaré - PE -18 (1)75-85.

41. JAXION-HARM, J. SAUNDERS, J., SPEIGHT, M.R. 2012. Distribution of fish in seagrass, mangroves and coral reefs: life-stage dependent habitat use in Honduras. Rev. Biol. Trop. 60, 683-98. https://doi.org/10.15517/rbt.v60i2.3984

42. KING M. 2007. Fisheries biology, assessment and management. 2nd edn. Blackwell Publishing, Oxford, UK. DOI: 10.1002/9781118688038

43. KNOPPERS, B.; EKAU, W.; FIGUEIREDO, A. G. 1999. The coast and shelf of east and northeast Brazil and material transport. Geo-Marine Letters, 19 (3), 171-178. https://doi.org/10.1007/s003670050106

44. LESSA, R.; NÓBREGA, M.F., 2000. Guia de Identificação de Peixes Marinhos da Região Nordeste. Programa REVIZEE, Score-NE. Recife, PE, Brazil, 128.

45. LESSA, R. P.; NÓBREGA, M. F.; BEZERRA JR, J. L.; SANTANA, F. M.; DUARTE NETO, P. J.; HAZIN, F. H. V.; MONTEIRO, A. 2004. Dinâmica de populações e avaliação de estoques dos recursos pesqueiros da região nordeste. Volume II. DIMAR, Departamento de Pesca-Universidade Federal Rural de Pernambuco, Recife-Brasil.

46. LESSA, R., VIEIRA, A. C. D. S., MONTEIRO, A., SANTOS, J. S., LIMA, M. M. D., CUNHA, E. J. D., OLIVEIRA, B. A. B. R. 2006. Diagnóstico da pesca no litoral do estado de Pernambuco. ISAAC, VJ; MARTINS, AS; HAIMOVICI, M.; ANDRIGUETTO FILHO, J. A pesca marinha e estuarina do Brasil no inicio do século XXI: recursos, tecnologias, aspectos socioeconômicos e institucionais. Belém: Universidade Federal do Pará, UFPA, 67-91.

47. LESSA, R. P.; NÓBREGA; M. F.; BEZERRA J.R., J.L.; MUNIZ, B.; TRAVASSOS, P.; HAZIN, F. H. V; OLIVEIRA J. L. 2009. Dinâmica das frotas Pesqueiras da Região Nordeste do Brasil. Martins \& Cordeiro LTDA: Fortaleza, 1. ed. $4,164$.

48. LindemAN, K. C. PUGliese, R., WAUGH, G. T., \& AULT, J. S. 2000. 
Developmental patterns within a multispecies reef fishery: management applications for essential fish habitats and protected areas. Bull. mar. sci., 66 (3), 929-956.

49. LINDEMAN, K.C., TOXEY, C.S. Haemulidae. In CARPENTER, K.E. (ed.). 2002. The living marine resources of the Western Central Atlantic. Vol. 3: Bony fishes part 2 (Opistognathidae to Molidae), sea turtles and marine mammals. FAO Species Identification Guide for Fishery Purposes and American Society of Ichthyologists and Herpetologists Special Publication No. 5. Rome, FAO.1522-1529.

50. LIRA A.S., VIANA A.P., EDUARDO L.N., LUCENA-FRÉDOU F., FRÉDOU T. 2019. Population structure, size at first sexual maturity, and feeding ecology of Conodon nobilis (Perciformes, Haemulidae) from the coast of Pernambuco, Northeastern Brazil. Acta Ichthyol. Piscat., 49(4). (In press).

51. LOPES, R. M. R., SOARES, I. A., \& DE ARAÚJO, J. S. S. 2014. Área de proteção ambiental dos recifes de corais-área dos parrachos de maracajaú/RN: desafios para o uso sustentável. Caminhos de Geografia, 15(51).

52. LOURENÇO L.S., SOUZA U.P., FERNANDES I.M., PETRERE M.JR. 2015. Spatiotemporal variation in life history traits of three small fishes in streams of south-eastern Brazil. Fisheries Manag Ecol. 22, 143-151. https://doi.org/10.1111/fme.12114

53. MADRID, J.; SÁNCHEZ, P.; RUIZ, A. 1997. Diversity and abundance of a tropical fishery on the Pacific shelf of Michoacán, Mexico. Estuar. Coast. Shelf Sci., 45 (4), 485-495. https://doi.org/10.1006/ecss.1996.0219

54. MARQUES, S.; FERREIRA, B. P. 2010 Composição e características da pesca de armadilhas no litoral Norte de Pernambuco-Brasil. Bol. Téc. Cient. do CEPENE, 18(1), 49-60.

55. MENEZES, N. A. 2011. Checklist dos peixes marinhos do Estado de São Paulo, Brasil. Biota Neotrop., 11 (1), 1-14. http://dx.doi.org/10.1590/S167606032011000500003

56. MOTOMURA, H.; HARAZAKI, S. 2017. Annotated checklist of marine and freshwater fishes of Yaku-shima island in the Osumi Islands, Kagoshima, southern Japan, with 129 new records. Kagoshima University Museum.

57. MUNRO, J. L. 1983, Caribbean coral reeffishery resources (Vol. 7). WorldFish.

58. MUNRO, J. L. 1996. The Scope of Tropical Reef Fisheries and Their Management. In: POLUNIN, N.C.V; ROBERTS, C.M. (Eds.) Reef Fisheries. Chapman \& Hall, London. 1-14.

59. OlAVO, G., COSTA, P. A. S., MARTINS, A. S. \& FERREIRA, B. P. 2011. Shelf-edge reefs as priority areas for conservation of reef fish diversity in the tropical

Atlantic. Aquat.

Conserv., $21,199-209$. 
https://doi.org/10.1002/aqc.1174

60. OLIVEIRA, M. T., OLIVEIRA, M. T., SANTOS, M. N., COELHO, R., MONTEIRO, V., MARTINS, A., \& LINO, P. G. 2015. Weight-length and length-length relationships for reef fish species from the Cape Verde Archipelago (tropical north-eastern Atlantic). J. Appl. Ichthyol., 31 (1), 236-241. https://doi.org/10.1111/jai.12497

61. OLSEN, E. M., HEINO, M., LILLY, G. R., MORGAN, M. J., BRATTEY, J., ERNANDE, B., \& DIECKMANN, U. 2004. Maturation trends indicative of rapid evolution preceded the collapse of northern cod. Nature, 428(6986), 932-935. https://doi.org/10.1038/nature02430

62. PASSARONE, R., APARECIDO, K. C., EDUARDO, L. N., LIRA, A. S., SILVA, L. V. S., JUSTINO, A. K., ... \& LUCENA-FRÉDOU, F. 2019. Ecological and conservation aspects of bycatch fishes: An evaluation of shrimp fisheries impacts in Northeastern Brazil. Brazilian Journal of Oceanography, 67. http://dx.doi.org/10.1590/s1679-87592019029106713

63. PEREIRA, P. H. C., BARROS, B., ZEMOI, R., \& FERREIRA, B. P. 2015. Ontogenetic diet changes and food partitioning of Haemulon spp. coral reef fishes, with a review of the genus diet. Rev. Fish Biol. Fish., 25 (1), 245-260. https://doi.org/10.1007/s11160-014-9378-2

64. PRATES, A. P. L., CORDEIRO, A. Z., FERREIRA, B. P., \& MAIDA, M. 2007. Unidades de conservação costeiras e marinhas de uso sustentável como instrumento para a gestão pesqueira. Áreas Aquáticas Protegidas como um Instrumento de Gestão Pesqueira. Brasília: Núcleo da Zona Costeira e Marinha, Ministério do Meio Ambiente (Eds.). artesanal: potencialidades e obstáculos no litoral do Estado de Santa Catarina. Ambiente \& Sociedade, Campinas, 9(2), 8387

65. QGIS Development Team. QGIS Geographic Information System. Open Source Geospatial Foundation Project. 2018. http://qgis.osgeo.org

66. RANGEL, C. A., CHAVES, L. C. T., MONTEIRO-NETO, C. 2007. Baseline assessment of the reef fish assemblage from Cagarras Archipelago, Rio de Janeiro, southeastern Brazil. Braz. J. of Oceanograp., 55 (1), 7-17. http://dx.doi.org/10.1590/S1679-87592007000100002

67. REAKA-KUDLA, M. L. 1997. The global biodiversity of coral reefs: a comparison with rain forests. Biodiversity II: Understanding and protecting our biological resources, 2, 551 .

68. RIBEIRO, F. P. 2006. A pesca de peixes demersais com armadilhas no nordeste do Brasil. Monitoramento dos recifes de coral do Brasil. (Eds BP Ferreira and M. Maida.) pp, 71-72.

69. ROCHA, L. A., LINDEMAN, K. C., ROCHA, C. R., LESSIOS, H. A. 2008. Historical biogeography and speciation in the reef fish genus Haemulon 
(Teleostei: Haemulidae). Mol. phylogenet. evol., 48 (3), 918-928. http://dx.doi.org/10.1016/j.ympev.2008.05.024

70. SHINOZAKI-MENDES, R. A., SANTANDER-NETO, J., SILVA, J. R. F., \& HAZIN, F. H. V. 2013a. Gonad maturation of Haemulon plumieri (Teleostei: Haemulidae) in Ceará state, northeastern Brazil. Braz. J. Biol.. 73 (2), p. 383390. http://dx.doi.org/10.1590/S1519-69842013000200019

71. SHINOZAKI-MENDES, R. A., SANTANDER-NETO, J., SILVA, J. R. F., \& HAZIN, F. H. V. 2013b. Reproductive biology of Haemulon plumieri (Teleostei: Haemulidae) in Ceará state, northeastern Brazil. Braz. J. Biol. 73, (2), 391-396. http://dx.doi.org/10.1590/S1519-69842013000200020

72. SILVA, A. M.; OLIVEIRA, M. R.; CHELLAPPA, S. 2012. Biologia reprodutiva do coró, Pomadasys corvinaeformis Steindachner (Osteichthyes: Haemulidae) das águas costeiras do Rio Grande do Norte, Brasil. Biota Amazônia, 2 (2), 1524. http://dx.doi.org/10.18561/2179-5746/biotaamazonia.v2n2p15-24

73. SILVA-JÚNIOR, C.A.B, LIRA, A.S, EDUARDO, L.N, VIANA, A.P, LUCENAFRÉDOU, F, FRÉDOU, T. 2019. Ichthyofauna bycatch of the artisanal fishery of penaeid shrimps in Pernambuco, Northeastern Brazil. Bol. Inst. Pesca, 45 (1), https://doi.org/10.20950/1678-2305.2019.45.1.435

74. SOARES, A.P.C, 2019. Padrões de distribuição e aspectos populacionais do saramunete (Pseudupeneus maculatus (Bloch, 1793)) na costa nordeste do Brasil. Dissertação (Mestrado em Recursos Pesqueiros e Aquicultura), Departamento de Pesca e Aquicultura, Universidade Federal Rural de Pernambuco. Recife.

75. SOUTER, D. W.; LINDEN, O. 2000. The health and future of coral reef systems. Ocean Coast. Manage. 43 (8-9), 657-688. https://doi.org/10.1016/S09645691(00)00053-3

76. SOUZA, A. T. D. E.; DI, M.; ILARRI, I.; MEDEIROS, P. R. D. E.; GREMPEL, G.; ROSA, R. S.; SAMPAIO, C. L. S. 2007. Zootaxa,Fishes (Elasmobranchii and Actinopterygii) of Picaozinho reef, Northeastern Brazil, with notes on their conservation status.
https://doi.org/10.11646/zootaxa.1608.1.2

77. TORREJÓN-MAGALLANES J.2016. sizeMat: Estimate Size at Sexual Maturity. R package version 0.3.0. [https://CRAN.R-project.org/package=sizeMat].

78. UYARRA, M. C.; WATKINSON, A. R.; COTE, I. M. 2009. Managing dive tourism for the sustainable use of coral reefs: validating diver perceptions of attractive site features. Environ. Manage., 43 (1), 1-16. doi: 10.1007/s00267008-9198-z.

79. VASCONCELOS-FILHO, J. E; LESSA, R. P. T.; SANTANA, F. M. 2018. Idade, crescimento e mortalidade de Haemulon plumierii capturada no estado de Pernambuco, Brasil. Bol. Inst. Pesca, 44 (4), 301-319. 
80. VAZZOLER, A. E. A. 1996. Biologia da reprodução de peixes teleósteos: teoria e prática. Maringá: Eduem/SBI/CNPq/Nupelia, pp 113.

81. WHITE, A., WHITE, A., HALE, L. Z., RENARD, Y., \& CORTESI, L. 1994. Collaborative and community-based management of coral reefs: lessons from experience. Kumarian Press. 
Figure Captions

Figure 1- Study site with bathymetry data and sample points along the continental shelf of Northeast Brazil RN $=5^{\circ}-6^{\circ} \mathrm{S}, \mathrm{PE}=6^{\circ}-7^{\circ} \mathrm{S}, \mathrm{PB}=7^{\circ}-8^{\circ} \mathrm{S}$ and $\mathrm{AL}=8^{\circ}-9^{\circ} \mathrm{S}$, surveyed on the expeditions of 2015 and 2017 of the project ABRACOS.

Figure 2- Habitat types classification by underwater video footage (Adapted from EDUARDO, 2018b) along the Northeast coast of Brazil.

Figure 3 - Size at first maturity, standard deviation and coefficients ( $A$ and $B ; p<0,05$ ) (a1, a2 and a3); and length frequency of females and males of Haemulidae on the Northeast coast of Brazil (red line indicates the estimated length at first maturity) (b1, b2 and b3). (a1, b1) H. plumierii; (a2, b2) H. aurolineatum and (a3, b3) H. squamipinna.

Figure 4 - CPUE of $H$. plumierii a) in number of individuals b) in biomass (kg) and (c) the ratio of adults and juveniles in the shelf (inner and outer) along the northeast coast of Brazil. The dashed line, in Figure $4 \mathrm{c}$ indicates the separation between the inner and outer shelves.

Figure 5 - CPUE of $H$. aurolineatum a) in number of individuals b) in biomass (kg) and (c) the ratio of adults and juveniles on the shelf (inner and outer) along the northeast coast of Brazil. The dashed line in Figure 5c indicates the separation between the inner and outer shelves.

Figure 6 - CPUE of $H$. squamipinna a) in number of individuals b) in biomass (kg) and (c) the ratio of adults and juveniles in the shelf (inner and outer) along the northeast coast of Brazil. The dashed line in figure $6 \mathrm{c}$ indicates the separation between the inner and outer shelves.

Figure 7 - CPUE of H. steindachneri in the number of individuals(a) and in biomass (kg) (b) on the northeast coast of Brazil.

Figure 8 - CPUE of $O$. ruber in number of individuals(a) and in biomass (kg) (b) on the northeast coast of Brazil. 


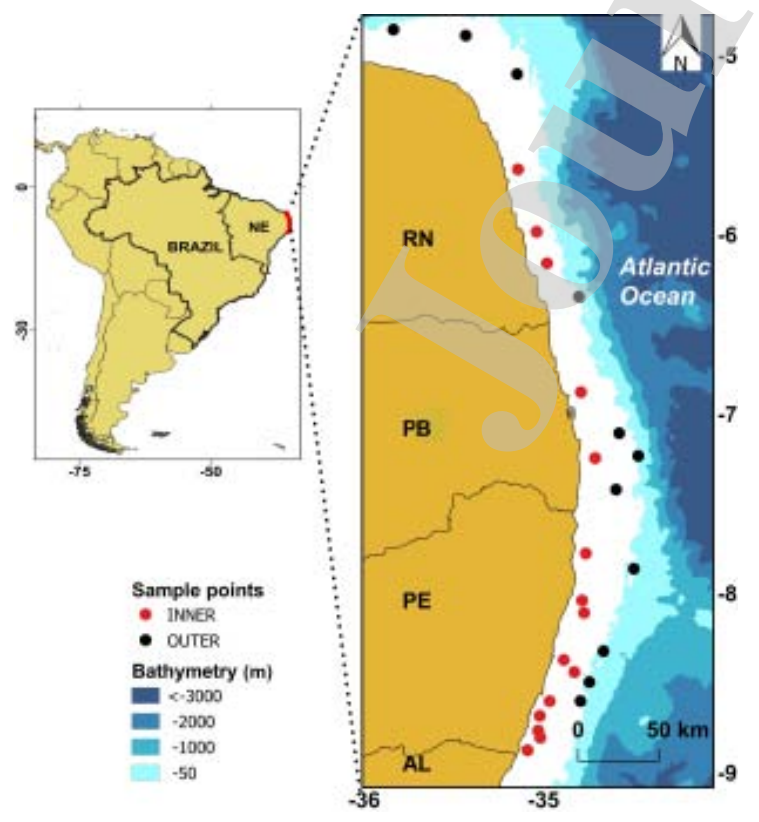




\section{Habitat classification}

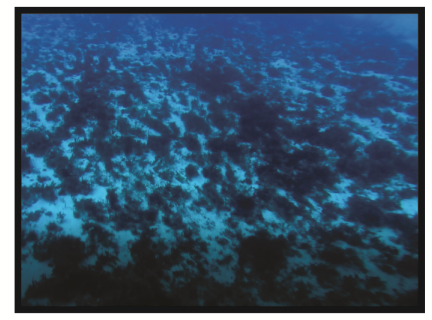

ALGAE

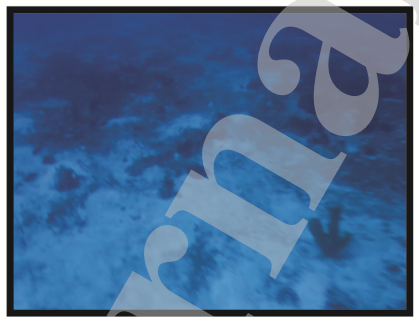

Sand with rocks, coralline formations and sponges (SWCR)

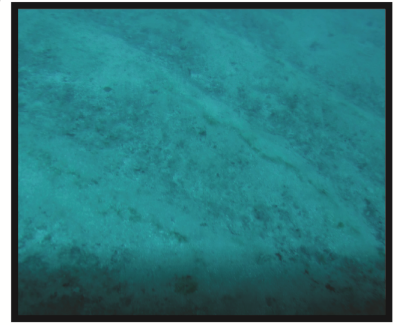

SAND

GPS

System

○
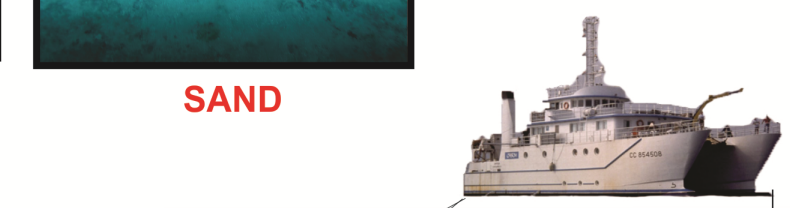

Scammar system to control net geometry and depth classify bottom habitat

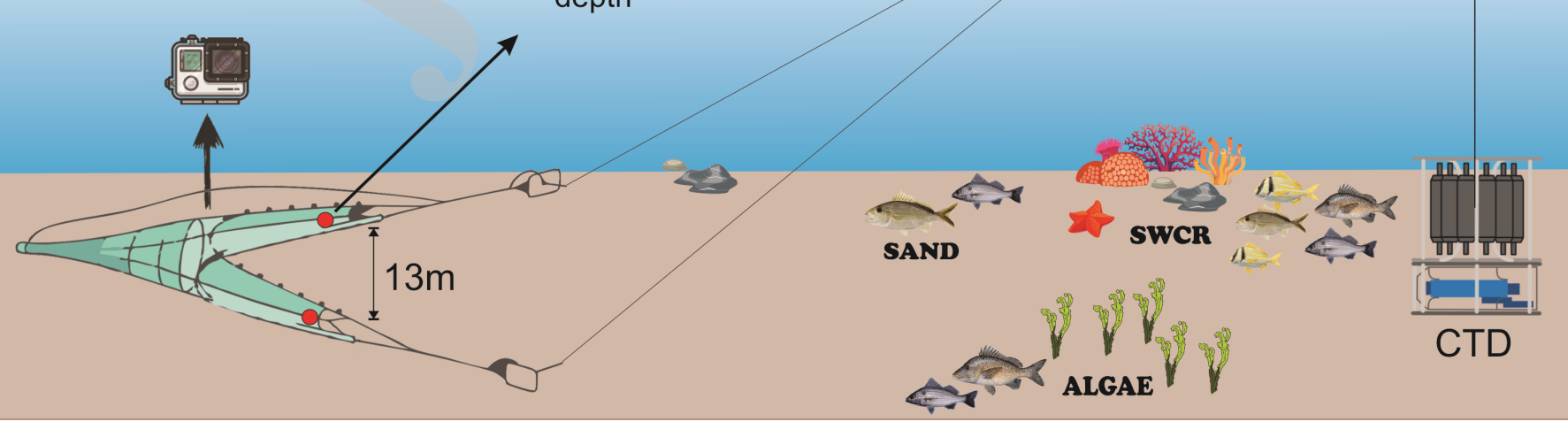



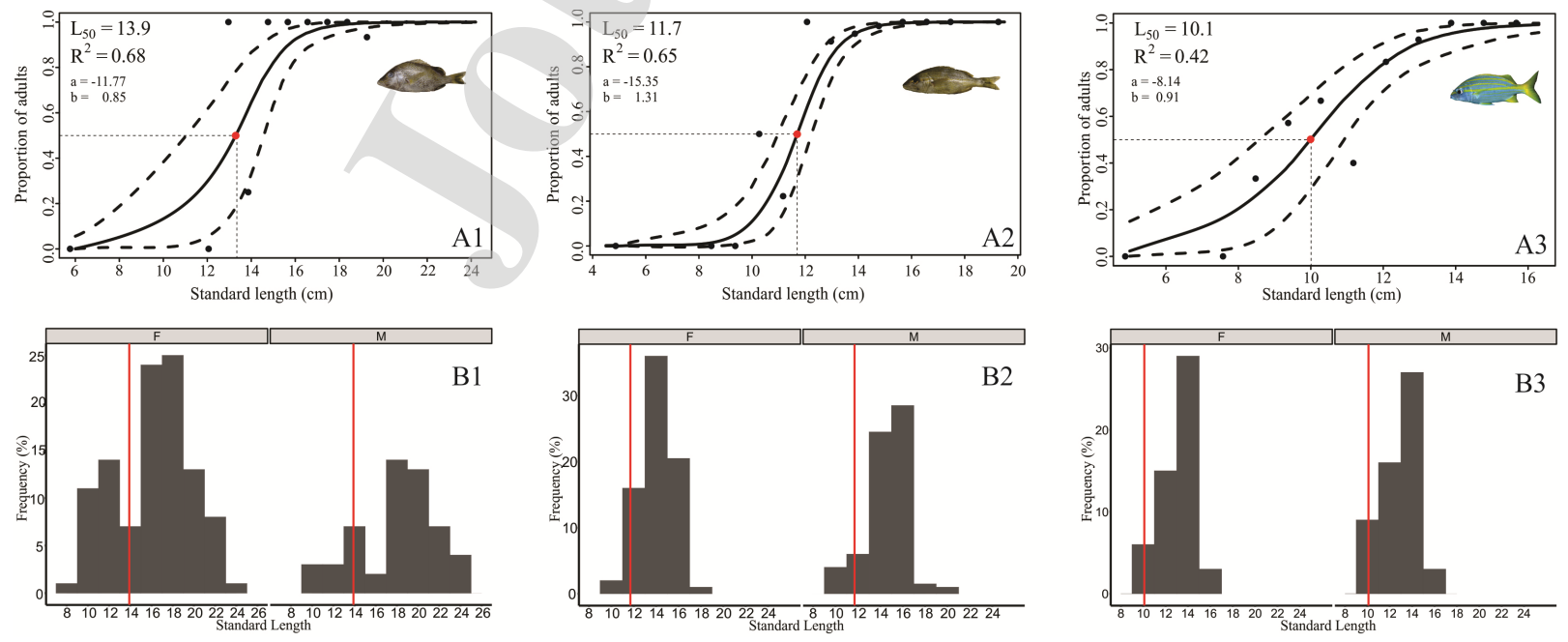


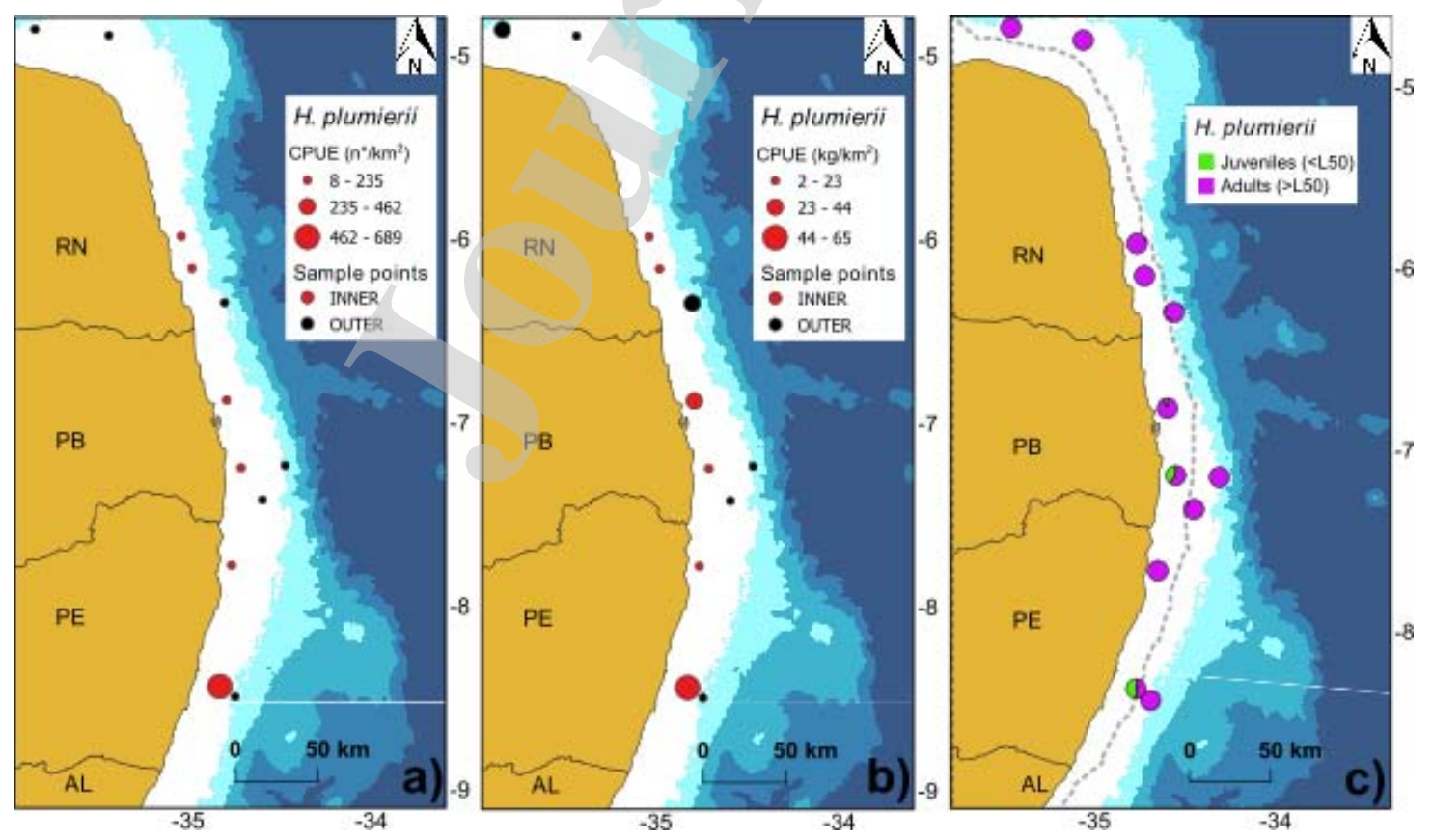




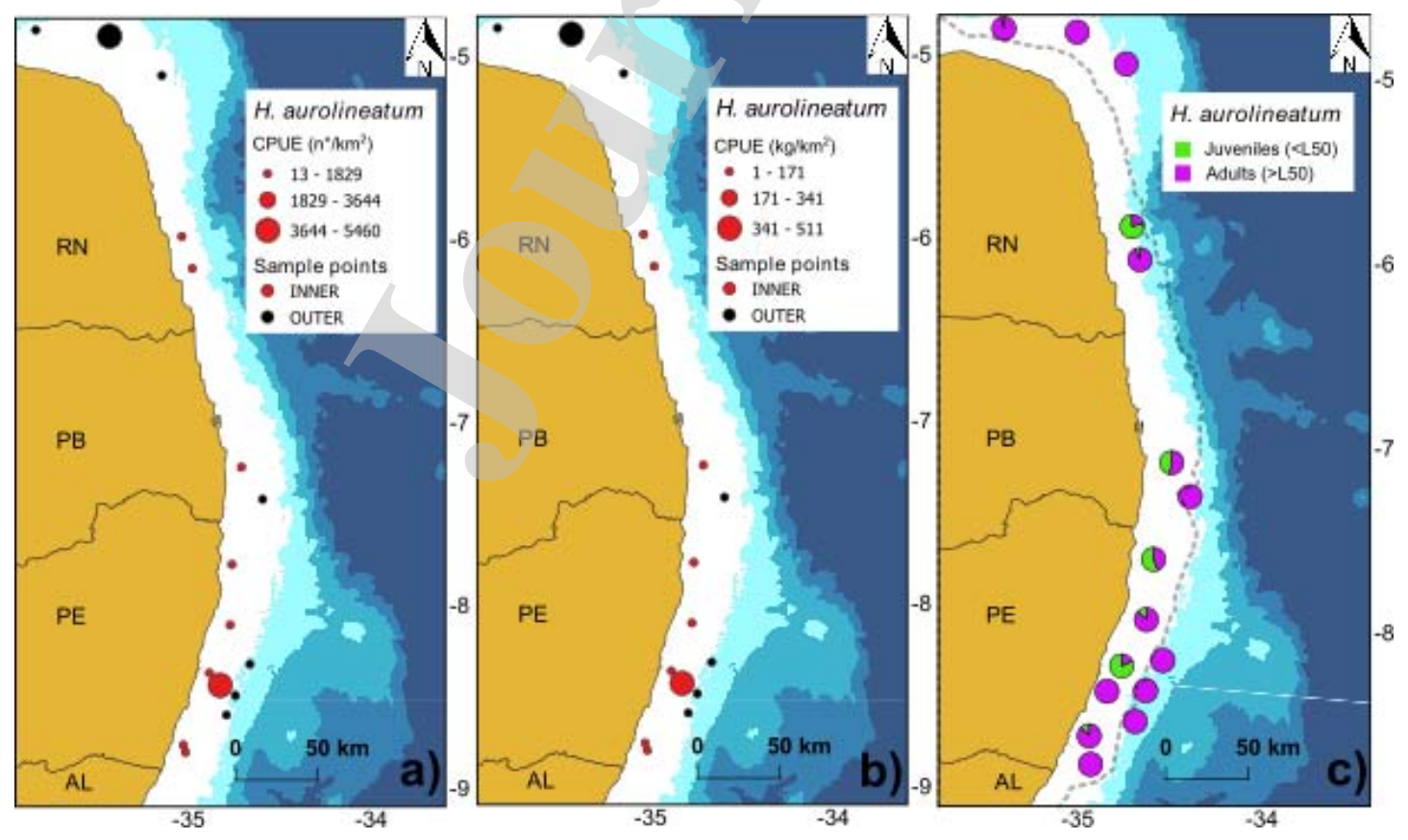




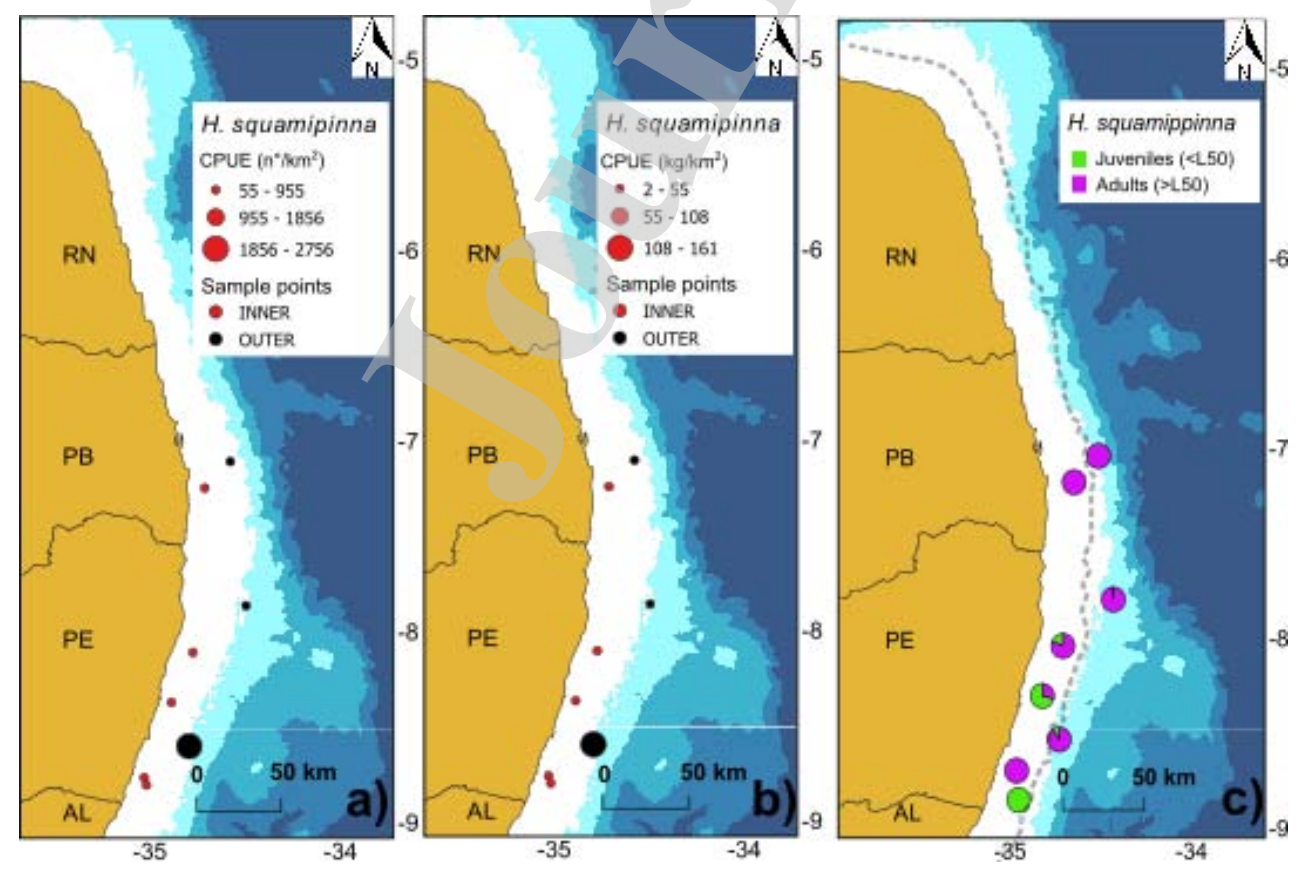




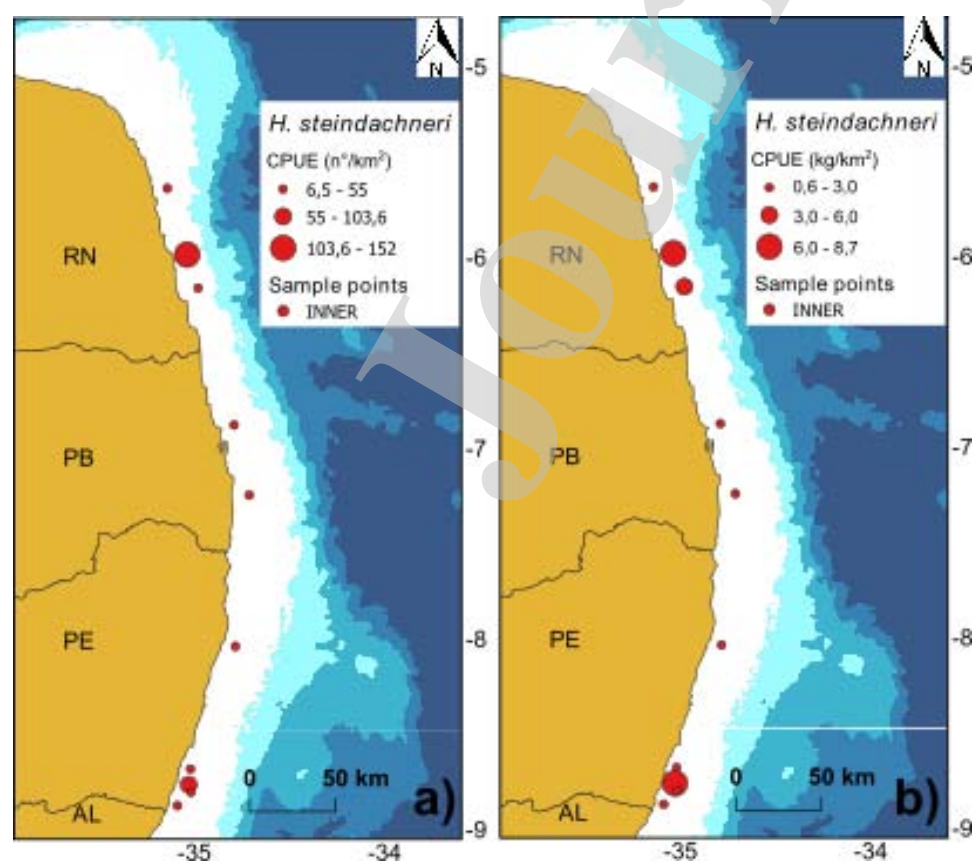




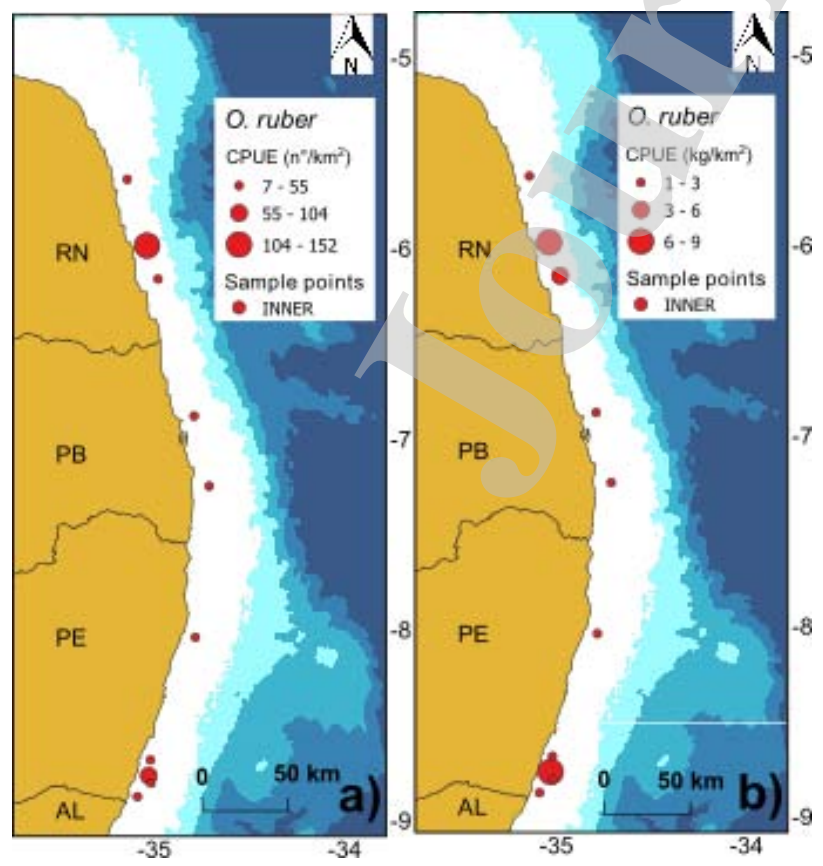


政

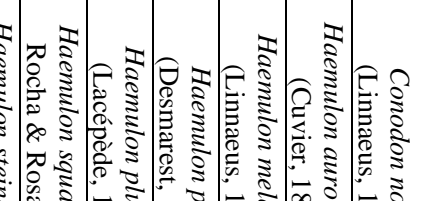

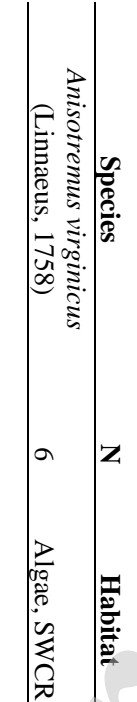

它说:

每

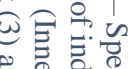

政

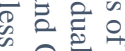

䒕劳官

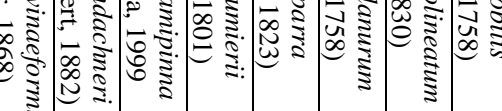

0
0

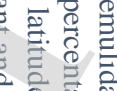

잉

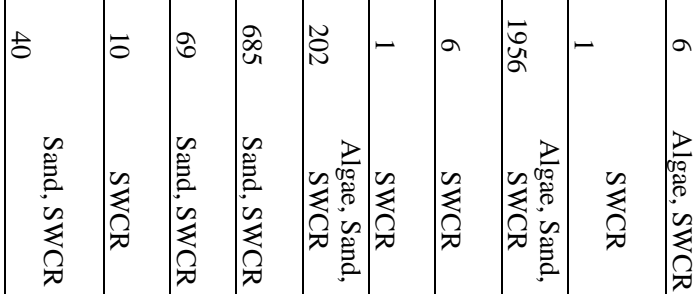

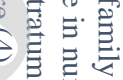

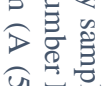

,

oิ do

당. 후

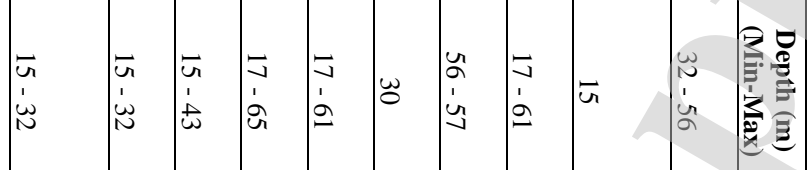

â

-

200

io

苞

$\forall$ 要

कoㅇㅇㅇ

定

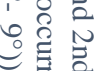

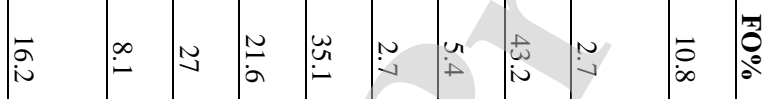

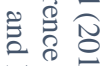

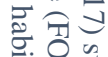

웡

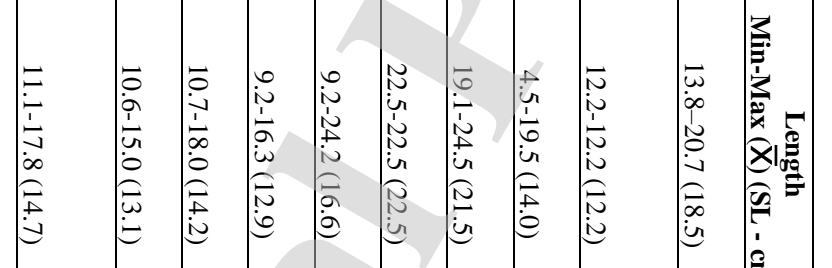

逢

吾容

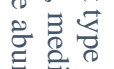

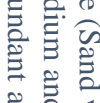

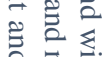

要要

究

要要

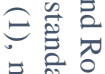

总

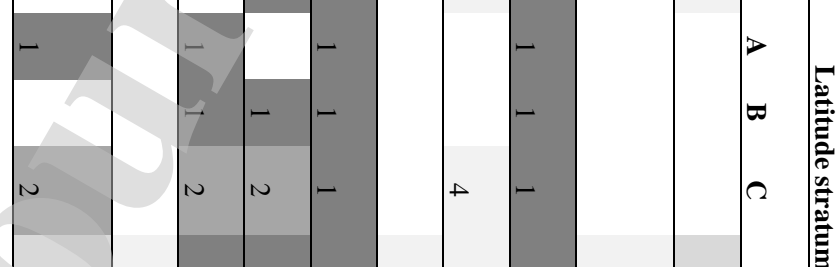

$\approx \quad$ 产离告

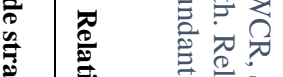

ह

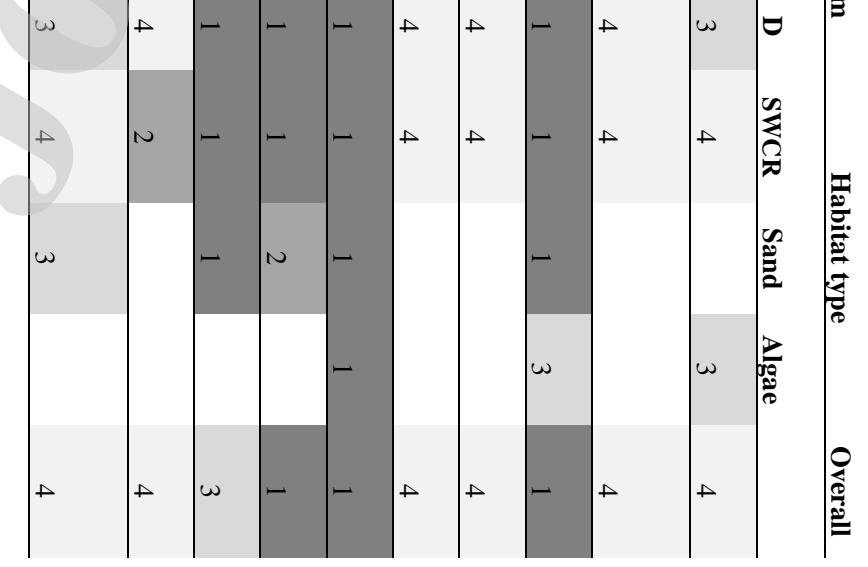

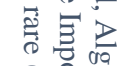

스율 है

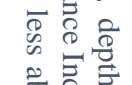

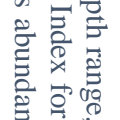

言离它 


\section{Highlights}

- Haemulidae are broadly distributed through Northeast coast of Brazil due to the complex habitat presents in this region.

- H. plumierii, H. aurolineatum and H. squamipinna were considered the most dominant species among the Family.

- The population structure, and size at first maturity were characterized for the most dominant species of Haemulidae (3 spp.) in Northeastern Brazil.

- The southern coasts of Pernambuco and Rio Grande do Norte hold high abundance, richness and concentration of juveniles. 
Catarina Cardoso de Melo

Universidade Federal Rural de Pernambuco

Departamento de Pesca e Aquicultura

52171-900, Recife, Pernambuco, Brazil

cmelo.catarina@gmail.com

February, 142019

\section{To: Editor of Regional Studies in Marine Science}

Dear Editor,

We are pleased to submit the revision of the research article entitled: "HAEMULIDAE DISTRIBUTION PATTERNS ALONG THE NORTHEASTERN BRAZILIAN CONTINENTAL SHELF AND SIZE AT FIRST MATURITY OF THE MOST ABUNDANT SPECIES" by Catarina Cardoso de Melo, Andrey P. Cavalcanti Soares, Latifa Pelage, Leandro Nole Eduardo, Thierry Frédou, Alex Souza Lira, Beatrice Padovani Ferreira, Arnaud Bertrand, and Flávia Lucena Frédou.

The authors have no conflict of interest and all have participated in the manuscript preparation and revision. See below a contribution's list of each author:

$\mathrm{AB}$ and FLF conceptualize and coordinated the research project. CCM performed analyses and wrote the manuscript with contributions of AB, ASL, APCS, LNE, LP, FLF, BPF and TF. Some authors participated of the at-sea surveys and contributed substantially on biological analyses. All the authors participated in the reviews of the language and referee's considerations.

Thank you for your consideration.

Sincerely.

Catarina Cardoso de Melo 


\section{Declaration of interests}

$\bigotimes$ The authors declare that they have no known competing financial interests or personal relationships that could have appeared to influence the work reported in this paper.

$\square$ The authors declare the following financial interests/personal relationships which may be considered as potential competing interests: 